\title{
FRIEDREICH ATAXIA: FXN GENE EXPRESSION AND ITS RELATIONSHIP WITH DNA METHYLATION PATTERN
}

Fedotova EYu凶, Abramycheva NYu, Nuzhny EP, Ershova MV, Klyushnikov SA, Illarioshkin SN

Research Center of Neurology, Moscow, Russia

Friedreich ataxia (FRDA) is the most common autosomal recessive ataxia associated with the non-coding GAA tandem repeats expansion in the FXN gene. Transcription impairment and frataxin protein deficiency are the key features of the disease pathogenesis. Our research was aimed to study the FXN gene mRNA expression as well as to carry out the clinical, genetic and epigenetic correlation analysis in a group of patients with homozygous expansion, in a group of their relatives with heterozygous expansion and in a control group. The FXN mRNA level was determined using the real-time polymerase chain reaction. Methylation pattern of $\mathrm{CpG}$ sites was evaluated by direct bisulfite sequencing. As a result of the study, the threshold values were obtained between the FRDA patients group, the group of heterozygous carriers and the control group (15 and 79\%, respectively). The clinical and genetic features comparison with the FXN expression level revealed no significant correlation. When comparing gene expression with an epigenetic profile, it was found that hypermethylation of a number of CpG sites upstream of the trinucleotide repeats and some non-CpG sites downstream of the region of repeats inhibited expression. Thus, the identified methylated sites may be considered as a target for epigenome editing to increase the FXN transcription and, consequently, for target therapy of the disease.

Keywords: Friedreich ataxia, gene expression, epigenetics, DNA methylation, non-CpG methylation, DNA diagnostics, target therapy

Funding: the study is supported by grant of the Russian Science Foundation (project № 17-75-20211).

Author contribution: all authors contributed to the study and preparation of the article equally, read and approved the final version before publishing.

Compliance with ethical standards: the study was approved by the Ethics Committee of Research Center of Neurology (protocol № 11-3/17 dated October 18, 2017). Informed consent was obtained from all study participants.

Correspondence should be addressed: Ekaterina Yu. Fedotova

Volokolamskoe shosse, 80, Moscow, 125367; ekfedotova@gmail.com

Received: 22.08.2019 Accepted: 13.09.2019 Published online: 25.09.2019

DOI: $10.24075 /$ brsmu.2019.062

\section{БОЛЕЗНЬ ФРИДРЕЙХА: ЭКСПРЕССИЯ ГЕНА ГХN И ЕЕ ВЗАИМОСВЯЗЬ С ОСОБЕННОСТЯМИ МЕТИЛИРОВАНИЯ ДНК}

\author{
Е. Ю. Федотова ${ }^{凶}$, Н. Ю. Абрамычева, Е. П. Нужный, М. В. Ершова, С. А. Клюшников, С. Н. Иллариошкин
}

Научный центр неврологии, Москва, Россия

\begin{abstract}
Болезнь Фридрейха (БФ) - наиболее частая аутосомно-рецессивная атаксия, связанная с экспансией тандемных некодирующих GАА-повторов в гене FXN. Нарушение транскрипции и недостаточность белка фратаксина являются ключевыми звеньями патогенеза заболевания. Целью работы было исследовать экспрессию мРНК гена FXN и провести анализ клинических, генетических и эпигенетических корреляций в группе пациентов с гомозиготной экспансией повторов, в группе их родственников с гетерозиготной экспансией и в контрольной группе. Уровень мРНК гена FХN определяли с помощью полимеразной цепной реакции в реальном времени. Паттерн метилирования СрG-сайтов оценивали методом прямого секвенирования после бисульфитной обработки. В результате работы получены разграничительные значения между группой пациентов БФ, группой гетерозиготных носителей и контрольной группой (15 и 79\% соответственно). При проведении клинико-генетических сопоставлений с уровнем экспрессии FХN значимых корреляций выявлено не было. При сопоставлении экспрессии гена с эпигенетическим просилем было установлено, что экспрессия подавляется при гиперметилировании ряда CpG-сайтов выше области тринуклеотидных повторов и некоторых не-СрG-сайтов ниже области повторов. Таким образом, выявленные сайты могут быть рассмотрены в качестве точки приложения таргетного эпигенетического редактирования для увеличения транскрипции FXN и, следовательно, для таргетной терапии заболевания.
\end{abstract}

Ключевые слова: болезнь Фридрейха, экспрессия гена, эпигенетика, метилирование ДНК, не-СрG-метилирование, ДНК-диагностика, таргетная терапия Финансирование: работа выполнена при поддержке гранта РНФ (номер проекта 17-75-20211).

Информация о вкладе авторов: все авторы внесли равнозначный вклад в проведение исследования и подготовку статьи, прочли и одобрили ее финальную версию перед публикацией.

Соблюдение этических стандартов: исследование одобрено этическим комитетом ФГБНУ НЦН (протокол № 11-3/17 от 18 октября 2017 г.). Все пациенты подписали информированное согласие на участие в исследовании.

$\triangle$ Для корреспонденции: Екатерина Юрьевна Федотова

Волоколамское ш., д. 80, г. Москва; ekfedotova@gmail.com

Статья получена: 22.08.2019 Статья принята к печати: 13.09.2019 Опубликована онлайн: 25.09.2019

DOI: $10.24075 /$ vrgmu.2019.062

Friedreich ataxia (FRDA) is the most common autosomal recessive ataxia associated with the GAA trinucleotide repeat expansions in intron 1 of the FXN gene [1, 2]. The molecular basis of the disease is the gene product deficiency (mitochondrial protein, frataxin) [3]. Large expansion containing hundreds of nucleotides observed in patients with FRDA inhibits transcription of the corresponding FXN mRNA [2].

A number of studies show that in the DNA critical locus containing the FXN gene, heterochromatin (inactive chromatin) is formed in presence of expansion demonstrating the transcription suppression [4]. This corresponds to histone modifications: acetylation decrease and trimethylation increase shown in patients with FRDA [5-7]. Along with the histone modification, other epigenetic phenomena are also observed: DNA hypermethylation in promoter region and in the intron 1 upstream of the GAA expansion (UP-GAA), as well as DNA hypomethylation in the intron 1 downstream of the GAA expansion (DOWN-GAA). It is known that cytosine methylation 
in the cytosine-guanine dinucleotide pair (CpG) of the promoter leads to the gene expression decrease, i.e., DNA methylation in the UP-GAA region presumably inhibits transcription of FXN and leads to a decrease in the frataxin level [8].

DNA methylation and histone modification are interconnected epigenetic mechanisms. In particular, DNA methylation level may be an important predictive marker for histone deacetylases inhibitors. Clinical trials of the latter are conducted with the aim of epigenetic therapy of FRDA. At the same time it is believed that in patients with FRDA, DNA methylation is primary in relation to histone modification [9].

In recent years papers emerged investigating the significance of so-called non-CpG methylation in which cytosine paired with nucleotides other than guanine (adenine, thymine, cytosine) was methylated. The highest level of non-CpG methylation was observed in stem cells and cells of the nervous system [10, 11], which suggested the special role of this epigenetic modification in the nervous system functions in normal and pathological conditions. To date, non-CpG methylation in FRDA patients has not been investigated.

Our research was aimed to study the FXN gene mRNA expression as well as to conduct the clinical, genetic and epigenetic correlation analysis in patients with FRDA and in heterozygous FXN mutation carriers.

\section{METHODS}

The study was conducted in the 5th Neurological Department of the Research Center of Neurology from 2017 to 2019. A group of patients with FRDA and confirmed homozygous GAA repeat expansion in the FXN gene was surveyed ( $n=8$; 3 women and 5 men). The average age of patients was $29.9 \pm 9.5$ years, the average age of onset was $13.8 \pm 6.7$ years, the disease duration was $16.0 \pm 9.3$ years. Inclusion criteria for the group of patients with FRDA: clinical diagnosis and positive results of molecular genetic testing (homozygous GAA tandem repeat expansion in introne 1 of the FXN gene). Average number of the GAA repeats in the short allele in the group was $506.0 \pm 232.0$ (GAA1), in the long allele the average number was $718.8 \pm 143.8$ (GAA2). Clinical examination of patients was performed using the SARA scale (mean score for the group $23.1 \pm 11.4$ ) and the Montreal Cognitive Assessment (MoCA) test (mean score $24.6 \pm 2.7)$. Cardiomyopathy (5/8), carbohydrate metabolism impairment (3/8), scoliosis and foot deformities (6/8) were also determined. Exclusion criteria: no clinical diagnosis.

The group of patients was compared with the group of heterozygous FXN gene mutation carriers designated hereinafter as GAA heterozygotes ( $n=6 ; 5$ women and 1 man). This group included the first-degree relatives of patients with FRDA. Comparison group included older people (53.7 \pm 19.6 years) compared to patients with FRDA (because of the parents of patients). For heterozygous patients the inclusion criterion was presence of the GAA expansion in the heterozygous state. The length of the expanded FXN allele in the group was $664.0 \pm 283.7$ repeats (GAA2). Control group $(n=10)$ with no GAA repeat expansion in the FXN gene was comparable in gender and age to the main group.

Genomic DNA samples were isolated from peripheral blood leukocytes using the Wizard Genomic DNA Purification Kit (Promega; USA). The GAA repeat expansion in the FXN gene was determined using the polymerase chain reaction (PCR) with subsequent separation of amplicons using the agarose gel.

Methylation pattern was determined by direct bisulfite sequencing of the corresponding DNA regions using the EZ
DNA Methylation Kit (Zymo Research; USA) according to the manufacturer's instructions. For each subject, the methylation level of CpG sites was determined in three main significant regions of the FXN gene: promoter region, UP-GAA region and DOWN-GAA region. $16 \mathrm{CpG}$ sites in the promoter region of FXN, $67 \mathrm{CpG}$ sites in the UP-GAA region and $21 \mathrm{CpG}$ sites in the DOWN-GAA region were explored (numeration starts from the $5^{\prime}$ end of the corresponding region). The degree of the site methylation was calculated by the ratio of the blue peak height (methylated cytosine, C) to the total height of the blue and red peaks (methylated and non- methylated cytosine, $\mathrm{C}+\mathrm{T}$ ).

Along with the $\mathrm{CpG}$ sites search and analysis of non-CpG sites methylation were performed. In non-CpG sites methylated cytosine was a precursor of adenine, thymine or cytosine (mCA, $\mathrm{mCT}, \mathrm{mCC}$ respectively).

The FXN expression level (the amount of mRNA of the FXN gene) was measured the by real-time PCR (RT-PCR) in the studied samples according to the following scheme. Peripheral blood samples were placed in the tubes with EDTA. Blood samples were pre-treated with a special buffer for red blood cells lysis, Buffer EL (QIAGEN; Germany), aliquoted and stored at $-80^{\circ} \mathrm{C}$. To isolate genomic RNA, the RNeasy Plus Mini Kit (QIAGEN; Germany) was used according to the manufacturer's protocol. Total cDNA from RNA samples was isolated using a kit for reverse transcription and cDNA amplification (Eurogen; Russia) with the addition of oligo (dT) primer, aliquoted and stored at $-20{ }^{\circ} \mathrm{C}$. The FXN gene mRNA level in the studied samples was determined by the threshold cycle using the RTPCR method with intercalating SYBR Green dye, normalized to the $G A P D H$ reference gene. The $2^{(-\Delta \Delta C t)}$ formula was used as a method of calculating the level of expression.

Statistical analysis was carried out using the IBM SPSS Statistics 23 software (IBM; USA). The nonparametric methods were used: Mann-Whitney $U$ test and Spearman rank correlation test. ROC curve analysis was performed using the MedCalc 18 software (MedCalc Software; Belgium).

\section{RESULTS}

\section{FXN gene expression in homozygous and heterozygous expansion carriers}

In the group of FRDA patients homozygous for the GAA repeat expansion the expression level was 0.05 [0.00; 0.127]. In the group of the patients relatives heterozygous for the expansion the expression level was 0.57 [0.54; 0.66], and in the control group it was $1.016[0.847 ; 1.214]$. The differences between the groups were significant $(p<0.05)$.

ROC curve analysis was performed based on the overlapping values of expression level obtained for the control group and for the group of GAA heterozygotes. The area under the curve for the analyzed indicator was 0.986 . For the demarcation threshold value equal to 0.79 , specificity was $95 \%$ and sensitivity was $93 \%$. In the ROC curve analysis of the gene expression evaluation in the groups of GAA heterozygotes and GAA homozygotes the area under the curve was 0.934 . For the demarcation threshold value equal to 0.15 , specificity was $93 \%$ and sensitivity was $87 \%$.

\section{Clinical comparison}

FXN expression was correlated with clinical data in the group of patients with FRDA. Correlation analysis did not reveal relationship between the expression level and the age of patients, the onset age and the duration of the disease, the SARA scale score 
and the MoCA test score $(p>0.05)$. According to the obtained data, expression level was not associated with cardiomyopathy, impaired carbohydrate metabolism or bone deformities ( $p>0.05)$.

In the comparison group among the relatives of patients the least FXN expression level was observed in the heterozygous GAA expansion carrier (750 GAA repeats) aged 72 (patient's mother). The subject had a history of long-term endocrinopathy (severe type 2 diabetes mellitus). In the GAA heterozygotes group there were no other patients with diabetes mellitus.

\section{Genetic comparison}

Correlation between the FXN mRNA expression level and the expanded allele length was studied. In the group of patients with FRDA expression was not associated with the shorter GAA1 allele length (no statistical significance) or with the longer GAA2 allele length. In the group of GAA heterozygotes no relationship between the expression level and the expanded GAA2 allele length was revealed.

\section{Epigenetic comparison}

The search for non-CpG sites was performed in all studied regions. Two non-CpG sites were identified in the promoter region, in the UP-GAA region there were no non-CpG sites, DOWN-GAA region contained 15 non-CpG sites.

Correlation analysis of the FRDA patients group revealed positive correlation between the FXN mRNA expression leve and the CpG-54 site of the UP-GAA region methylation level $(r=0.782 ; p=0.037)$. Negative correlation between the FXN expression level and the methylation level of three non-CpG sites of the DOWN-GAA region was revealed: non-CpG-7a $(r=-0.788 ; p=0.035)$, non-CpG-7b $(r=-0.795 ; p=0.032)$ and non-CpG-8a $(r=-0.875 ; p=0.009)$. No relationship of the methylation level of these non-CpG sites with the length of GAA1 or GAA2 was detected. At the same time, in adjacent
CpG sites, methylation did not correlate with expression, but depended on the length of the expanded allele (Table 1).

In the comparison group among the GAA heterozygotes, correlation between the expression level and the CpG-13 methylation level in the promoter region was detected $(r=-0.947 ; p=0.017)$, as well as correlation between the expression level and the CpG-3 methylation level in the DOWN-GAA region $(r=-0.894 ; p=0.041)$.

Given the small number of subjects in the groups, we calculated correlations in a combined group of patients, relatives and healthy volunteers, adjusted for the group. The revealed correlations between the FXN expression level and the individual sites methylation level are presented in Table 2. Summarizing the results, it can be noted that negative correlation between gene expression and methylation in the promoter and UP-GAA region and positive correlation between gene expression and methylation in the DOWN-GAA region were revealed for $\mathrm{CpG}$ sites, whereas in the DOWN-GAA region negative correlation was detected for non-CpG sites.

Methylated cytosine in the non-CpG sites was a precursor of the following nucleotides: mCCC (site 5a), mCTT (site 7a), mCCC (site 7b), mCAG (site 8a), mCAT (site 8b), mCTG (site 10b).

In the combined group, the degree of methylation of nonCpG sites of the DOWN-GAA region did not correlate with the expansion length (GAA1, GAA2) - similar to the group of FRDA patients.

\section{DISCUSSION}

Frataxin protein deficiency in patients with FRDA has a systemic effect and leads to different neurological and extraneurological manifestations [1, 9]. The severity of genetic changes in patients with FRDA (the expansion length of GAA repeats) can only partially explain the variety of clinical manifestations associated with the disorder (variable onset age and rate of progression, clinical manifestation features, polyneuropathy and corticospinal tract involvement, severity of cardiomyopathy, carbohydrate

Table 1. Correlation of the FXN gene expression level and the shorter allele repeat expansion length with the methylation level of DOWN-GAA region non-CpG sites and adjacent $\mathrm{CpG}$ sites in patients with FRDA

\begin{tabular}{|c|c|c|c|c|}
\hline Site identificators & $\begin{array}{l}\text { Correlation }{ }^{\#} \text { of methylation level } \\
\text { with expression }\end{array}$ & $\begin{array}{l}\text { Correlation* of methylation level } \\
\text { with GAA1 length }\end{array}$ & $\begin{array}{l}\text { Nucleotides following the } \\
\text { methylated cytosine }\end{array}$ & $\begin{array}{l}\text { Cytosine position } \\
\text { (GRCh38) }\end{array}$ \\
\hline CpG-7 & - & $-0.901^{*}$ & $\mathrm{mCG}$ & chr9:69.037.380 \\
\hline non-CpG-7a & $-0.788^{*}$ & - & $\mathrm{mCTT}$ & chr9:69.037.382 \\
\hline non-CpG-7b & $-0.795^{\star}$ & - & $\mathrm{mCCC}$ & chr9:69.037.388 \\
\hline CpG-8 & - & $-0.836^{\star}$ & $\mathrm{mCG}$ & chr9:69.037.390 \\
\hline non-CpG-8a & $-0.875^{\star}$ & - & mCAG & chr9:69.037.397 \\
\hline CpG-9 & - & $-0.772^{*}$ & $\mathrm{mCG}$ & chr9:69.037.420 \\
\hline CpG-10 & - & $-0.791^{\star}$ & $\mathrm{mCG}$ & chr9:69.037.434 \\
\hline
\end{tabular}

Note: \# - Spearman's rank correlation coefficient $(r) ;{ }^{\star}-p<0.05$; «-» - no correlation; mC — methylated cytosine.

Table 2. Correlation of the FXN gene level expression and the methylation level of sites in all studied regions in a combined cohort adjusted for the group

\begin{tabular}{|c|c|}
\hline Promoter: negative correlations & DOWN-GAA: positive correlations \\
\hline $\begin{array}{l}\text { - CpG-5 }(r=-0.511)^{\star} \\
\text { - CpG-13 }(r=-0.542)^{\star} \\
\text { - CpG-16 }(r=-0.511)^{\star}\end{array}$ & $\begin{array}{l}\text { - CpG-2 }(r=0.567)^{\star} \\
\text { - CpG-12 }(r=0.520)^{*}\end{array}$ \\
\hline UP-GAA: negative correlations & DOWN-GAA: negative correlations \\
\hline $\begin{array}{l}\text { - CpG-43 }(r=-0.615)^{*} \\
\text { - CpG-44 }(r=-0.508)^{\star} \\
\text { - CpG-45 }(r=-0.533)^{*}\end{array}$ & $\begin{array}{l}\text { - non-CpG-5a }(r=-0.514)^{\star} \\
\text { - non-CpG-7a }(r=-0.571)^{\star} \\
\text { - non-CpG-7b }(r=-0.506)^{\star} \\
\text { - non-CpG-8a }(r=-0.625)^{\star} \\
\text { - non-CpG-8b }(r=-0.644)^{\star} \\
\text { - non-CpG-10b }(r=-0.540)^{\star}\end{array}$ \\
\hline
\end{tabular}

Note: ${ }^{*}-p<0.05$. 
metabolism disorders etc.). As a consequence, the search for such a wide phenotypic polymorphism explanation was carried out by studying the factors and processes which regulate the implementation of genetic information: DNA methylation, histone modification, spatial organization of DNA, antisense transcripts and non-coding RNA. Due to the complexity and versatility of the processes caused by intron GAA expansion, it has not yet been possible to identify the main targets, the impact on which would help us to solve the problem of frataxin deficiency and impaired transcription of FXN, and, therefore, offer an effective therapeutic strategy. The focus of our study was on one of the epigenetic factors, DNA methylation. This factor seems promising in the view of studies in the field of targeted epigenetic editing, which may allow restoration of the impaired transcription, as it was demonstrated by the example of the FMR1 gene trinucleotide repeats expansion [12-14].

Results of the FXN expression degree investigation were presented in a number of foreign papers. Thus, in one of the papers, the level of FXN mRNA in patients with FRDA was reduced to $19 \%$ and in heterozygous carriers to $53 \%$ of the control level. At the same time, the mRNA level correlated with the level of frataxin, the age of the onset and the length of expansion [15]. In another study, comparable results were obtained. It was also demonstrated that mRNA level and the level of frataxin protein were relatively stable over time and changed against the background of epigenetic therapy (inhibitor of histone deacetylases) effect. In other words, the mRNA level is a measurable and variable indicator that can be used in clinical trials [16].

Our analysis of FXN gene expression also revealed a significant decrease in mRNA level in patients with homozygous GAA expansion (below 15\%) in relation to the control group, as well as in the group of relatives with heterozygous repeat expansion (below 79\%). However, in our study, statistically significant correlation with neither clinical nor genetic characteristics was detected, most likely due to the small sample size. At the same time, it is noteworthy that in the group of heterozygotes the lowest level of FXN mRNA was detected in a patient with type 2 diabetes mellitus. Possibly, a low level of expression of mRNA and frataxin protein in heterozygotes may be markers of the carbohydrate metabolism disorders observed in patients with FRDA which can also be detected in their relatives (heterozygous mutation carriers) [17, 18].

There are few papers on DNA methylation studies in patients with FRDA [8, 19-23]. Nevertheless, FRDA is considered a model disease characterized with a special type of trinucleotide repeat expansion (both alleles are in the non-coding, regulatory region of the gene) [20]. In two papers, hypermethylation of several sites was discovered in the UP-GAA region in patients with FRDA [21, 22]. Other researchers also noted UP-GAA hypermethylation and detected DOWN-GAA hypomethylation in patients' peripheral blood cells, in the brain and myocardium [23], which confirmed the systemic effect of the GAA repeat expansion and the information value of data obtained for peripheral blood leukocytes. In another study, in addition to UP-GAA hypermethylation and DOWN-GAA hypomethylation, a large sample of patients with FRDA demonstrated a negative correlation between the methylation level of one UP-CpG site and the FXN mRNA level [8]. mRNA level also correlated with GAA repeats number, onset age and symptoms severity. In our previously published paper [19] hypermethylation of the UPGAA region and hypomethylation of the DOWN-GAA region in patients with FRDA were confirmed, a direct relationship between the degree of methylation of UP-GAA region sites and the expansion length of homozygous mutation carriers, as well as inverse relationship between the degree of methylation of DOWN-GAA region sites with expansion length in heterozygous mutation carriers were detected.

Our present study is the continuation of the previous studies. The study is aimed to investigate the FXN epigenetic profile effect on the corresponding mRNA expression. Comparing the results of previous and present studies, it can be noted that hypermethylation of individual CpG sites located upstream of the repeats region (promoter and UP-GAA) is associated with a lower mRNA level and a larger number of GAA tandem repeats in the FXN gene. Hypomethylation of individual CpG sites in the DOWN-GAA region is associated with a lower mRNA level and a larger number of GAA tandem repeats.

As it is mentioned above, non-CpG methylation in patients with FRDA has not yet been investigated. The functional significance of non-CpG sites is discussed. However, it is now clear that it is very important for expression regulation [24]. Non-CpG sites are predominantly located in the regions with lower density of $\mathrm{CpG}$ sites, i.e., usually inside the gene. Methylation of non-CpG inside the gene is associated with a decrease in its expression. It is believed that compared to CpG methylation of non-CpG sites is more susceptible to changes that occur during the development and under the influence of various environmental factors [25]. Thus, in neurons at the embryo stage, non-CpG sites are almost not methylated. Non$\mathrm{CpG}$ methylation occurs during development. It is neurons that account for the largest part of adult non-CpG methylation, less for glia, stem cells, gametes. Non-CpG methylation is almost absent in other cells. Estimated ratio of non-CpG methylation to $\mathrm{CpG}$ methylation in neurons is $1: 3$. Most often, the first occurs in the CpA dinucleotide, to a lesser extent in the CpT dinucleotide, and even less in $\mathrm{CpC}$. It is believed that the function of non-CpG methylation depends on the molecular context. Thus, methylation of cytosine in the mCAC sequence can lead to a decrease in gene expression, while methylation in mCAG can lead to its increase [10, 11].

In our study 2 non-CpG sites were identified in the promoter region, in UP-GAA there were no non-CpG sites, DOWNGAA region contained 15 non-CpG sites. For comparison, the incidence of $\mathrm{CpG}$ in the same sequenced regions was as follows: $16 \mathrm{CpG}$ in the promoter, $67 \mathrm{CpG}$ in the UP-GAA and 21 $\mathrm{CpG}$ in the DOWN-GAA region. The provided data demonstrate that the higher the density of $\mathrm{CpG}$, the lower the occurrence of non-CpG, and vice versa. Approximate, conditional ratio of non-CpG to $\mathrm{CpG}$ is $1: 6$. It should be reminded, that the study was performed on blood leukocytes with a lower proportion of non-CpG, and not on neurons.

No correlation between the methylation level of two nonCpG sites in the FXN promoter region and the mRNA level was detected. A cluster of interconnected, adjacent non-CpG sites was identified in the DOWN-GAA region, methylation of which negatively correlates with the mRNA level. There was no relationship between the methylation level and the GAA expansion length. The unidirectional effect of all 6 detected nonCpG sites on the expression did not depend on the context, it was shown in the CpA (mCAC, mCAG), CpT (mCTT, mCTG), and $\mathrm{CpC}(2 \mathrm{mCCC})$ configurations.

In the combined cohort, in contrast to non-CpG methylation, the level of CpG methylation in DOWN-GAA demonstrated direct associative relationship with the mRNA level, which suggested a possible multidirectional effect of those two types of methylation. Another difference between the types may be the dependence on the length of GAA expansion: it is present in $\mathrm{CpG}$ methylation, whereas in the case of non-CpG it cannot 
be detected. Therefore, the non-CpG methylation can modify the expression of $F X N$ regardless of a genetic defect.

The identified cluster of closely located non-CpG sites, methylation of which is associated with the decrease in the FXN gene transcription, is in the distance from the regulatory sequences and binding sites of known and studied in patients with FRDA transcription factors, CTCF, SRF, TFAP2, EGR3, E-box (all transcription factors lie inside the promoter and the UP-GAA region) [26, 27]. The region of the detected non-CpG cluster, being inside the DOWN-GAA region, is a part of the Alu (SINE) element. The functional significance of the latter is not clear completely, however, removal of the element leads to a significant impairment of FXN transcription [4, 21]. This once again confirms the possible significance of non-CpG methylation in this region for transcription.

\section{References}

1. Illarioshkin SN., Ershova MV. Ataksiya Fridreykha. V knige: Illarioshkin SN, Rudenskaya GE, Ivanova-Smolenskaya IA. Markova ED, Klyushnikov SA. Nasledstvennye ataksii i paraplegii. M., 2006; s.49-113. Russian.

2. Burk K. Friedreich ataxia: current status and future prospects. Cerebellum Ataxias. 2017; (4): 4.

3. Deutsch EC, Oglesbee D, Greeley NR, Lynch DR. Usefulness of frataxin immunoassays for the diagnosis of Friedreich ataxia. $J$ Neurol Neurosurg Psychiatry. 2014; 85 (9): 994-1002.

4. Yandim C, Natisvivli T, Festenstein R. Gene regulation and epigenetics in Friedreich's ataxia. Journal of neurochemistry. 2013: 126 (Suppl. 1): 21-42.

5. Herman D, Jenssen K, Burnett R, Soragni E, Perlman SL, Gottesfeld JM. Histone deacetylase inhibitors reverse gene silencing in Friedreich's ataxia. Nat Chem Biol. 2006; 2 (10): 551-8.

6. Sandi C, Sandi M, Virmouni SA, Al-Mahdawi S, Pook MA Epigenetic-based therapies for Friedreich ataxia. Frontiers in Genetics. 2014; (5): 165

7. Soragni E, Miao W, ludicello M, Jacoby D, De Mercanti S, Clerico M, et al. Epigenetic therapy for Friedreich ataxia. Ann Neurol. 2014; 76 (4): 489-508.

8. Evans-Galea MV, Carrodus N, Rowley SM, Corben LA, Tai G, Saffery R, et al. FXN methylation predicts expression and clinical outcome in Friedreich ataxia. Ann Neurol. 2012; 71 (4): 487-97.

9. Blair IA, Farmer J, Hersch S, Larkindale J, Lynch DR, Napierala J, et al. The current state of biomarker research for Friedreich's ataxia: a report from the 2018 FARA biomarker meeting. Future Sci OA. 2019; 5 (6): FSO398.

10. He Y, Ecker JR. Non-CG methylation in the human genome. Annu Rev Genomics Hum Genet. 2015; (16): 55-77.

11. Jang HS, Shin WJ, Lee JE, Do JT. CpG and non-CpG methylation in epigenetic gene regulation and brain function. Genes. 2017; (8): e148.

12. Liu XS, Wu H, Krzisch M, Wu X, Graef J, Muffat J, et al. Rescue of Fragile $X$ syndrome neurons by DNA methylation editing of the FMR1 gene. Cell. 2018; (172): 979-92.

13. Lau $\mathrm{C}-\mathrm{H}$, Suh $\mathrm{Y}$. In vivo epigenome editing and transcriptional modulation using CRISPR technology. Transgenic Res. 2018; 27 (6): 489-509

14. Gomez JA, Beitnere U, Segal DJ. Live-animal epigenome editing: Convergence of novel techniques. Trends Genet. 2019; 35 (7): 527-41.

15. Sacca F, Puoro G, Antenora A, Marsili A, Denaro A, Piro R, et al. A combined nucleic acid and protein analysis in Friedreich ataxia: Implications for diagnosis, pathogenesis and clinical trial design. PLOS ONE. 2011; 6 (3): e17627.

\section{CONCLUSION}

The paper presents a comparison of the clinical parameters, the degree of expansion of GAA repeats, and the epigenetic characteristics of the FXN gene with the mRNA level in the group of patients with FRDA, in the group of their heterozygous relatives, and in the control group. FXN methylation sites significant for expression were identified. For a number of $\mathrm{CpG}$ sites in the promoter region and in the UP-GAA region, a negative correlation between methylation and the level of gene expression was determined, as well as for a number of non-CpG sites in the DOWN-GAA region. Thus, the identified hypermethylated cluster of non-CpG sites may be considered the application point for targeted epigenome editing needed for the FXN transcription increase, and, consequently, for FRDA target therapy.

16. Plasterer $\mathrm{HL}$, Deutsch EC, Belmonte M, Egan E, Lynch DR, Rusche JR. Development of frataxin gene expression measures for the evaluation of experimental treatment in Friedreich's ataxia. PLoS ONE. 2013; 8 (5): e63958.

17. Hebinck J, Hardt C, Schols L, Vorgerd M, Briedigkeit L, Kahn CR, Ristow M. Heterozygous expansion of the GAA tract of the X25/ frataxin gene is associated with insulin resistance in humans. Diabetes. 2000; 49 (9): 1604-7.

18. McCormick A, Farmer J, Perlman S, Delatycki M, Wilmot G, Matthews K, et al. Impact of diabetes in the Friedreich ataxia clinical outcome measures study. Annals of Clinical and Translational Neurology. 2017; 4 (9): 622-31.

19. Abramycheva NYu, Fedotova EYu, Nuzhniy EP, Nikolaeva NS, Klyushnikov SA, Ershova MV, i dr. Epigenetika bolezni Fridreykha: metilirovanie oblasti ekspansii (GAA)n-povtorov gena FXN. Vestnik Rossiyskoy akademii meditsinskikh nauk. 2019; 74 (2): 80-7.

20. Essebier A, Wolf PV, Cao MD, Carroll BJ, Balasubramanian S, Boden M. Statistical enrichment of epigenetic states around triplet repeats that can undergo expansions. Front Neurosci. 2016; (10): 92

21. Greene E, Mahishi L, Entezam L, Kumari D, Usdin K. Repeatinduced epigenetic changes in intron 1 of the frataxin gene and its consequences in Friedreich ataxia. Nucleic Acids Research. 2007; 35 (10): 3383-90.

22. Castaldo I, Pinelli M, Monticelli A, Acquaviva F, Giacchetti M, Filla $A$, et al. DNA methylation in intron 1 of the frataxin gene is related to GAA repeat length and age of onset in Friedreich ataxia patients. J Med Genet. 2008; 45 (12): 808-12.

23. Al-Mahdawi S, Pinto RM, Ismail O, Varshney D, Lymperi S, Sandi C, et al. The Friedreich ataxia GAA repeat expansion mutation induces comparable epigenetic changes in human and transgenic mouse brain and heart tissues. Hum Mol Genet. 2008; (17): 735-46.

24. Patil $\mathrm{V}$, Ward RL, Hesson LB. The evidence for functional non-CpG methylation in mammalian cells. Epigenetics. 2014; 9 (6): 823-28.

25. Fuso A, Lucarelli M. CpG and non-CpG methylation in the dietepigenetics-neurodegeneration connection. Curr Nutr Rep. 2019; 8 (2): 74-82.

26. Li K, Singh A, Crooks DR, Dai X, Cong Z, Pan L, et al. Expression of human frataxin is regulated by transcription factors SRF and TFAP2. PLoS ONE. 2010; 5 (8): e12286.

27. Al-Mahdawi S, Sandi C, Pinto RM, Pook MA. Friedreich ataxia patient tissues exhibit increased 5-hydroxymethylcytosine modification and decreased CTCF binding at the FXN locus. PLoS ONE. 2013; 8 (9): e74956. 


\section{Литература}

1. Иллариошкин С. Н., Ершова М. В. Атаксия Фридрейха. В книге: Иллариошкин С. Н., Руденская Г. Е., Иванова-Смоленская И. А., Маркова Е. Д., Клюшников С. А. Наследственные атаксии и параплегии. М., 2006; с. 49-113.

2. Burk K. Friedreich ataxia: current status and future prospects. Cerebellum Ataxias. 2017; (4): 4

3. Deutsch EC, Oglesbee D, Greeley NR, Lynch DR. Usefulness of frataxin immunoassays for the diagnosis of Friedreich ataxia. J Neurol Neurosurg Psychiatry. 2014; 85 (9): 994-1002.

4. Yandim C, Natisvivli T, Festenstein R. Gene regulation and epigenetics in Friedreich's ataxia. Journal of neurochemistry. 2013: 126 (Suppl. 1): 21-42.

5. Herman D, Jenssen K, Burnett R, Soragni E, Perlman SL, Gottesfeld JM. Histone deacetylase inhibitors reverse gene silencing in Friedreich's ataxia. Nat Chem Biol. 2006; 2 (10): 551-8.

6. Sandi C, Sandi M, Virmouni SA, Al-Mahdawi S, Pook MA. Epigenetic-based therapies for Friedreich ataxia. Frontiers in Genetics. 2014; (5): 165.

7. Soragni E, Miao W, ludicello M, Jacoby D, De Mercanti S, Clerico M, et al. Epigenetic therapy for Friedreich ataxia. Ann Neurol. 2014; 76 (4): 489-508.

8. Evans-Galea MV, Carrodus N, Rowley SM, Corben LA, Tai G, Saffery $R$ et al. FXN methylation predicts expression and clinical outcome in Friedreich ataxia. Ann Neurol. 2012; 71 (4): 487-97.

9. Blair IA, Farmer J, Hersch S, Larkindale J, Lynch DR, Napierala J et al. The current state of biomarker research for Friedreich's ataxia: a report from the 2018 FARA biomarker meeting. Future Sci OA. 2019; 5 (6): FSO398.

10. He Y, Ecker JR. Non-CG methylation in the human genome. Annu Rev Genomics Hum Genet. 2015; (16): 55-77.

11. Jang HS, Shin WJ, Lee JE, Do JT. CpG and non-CpG methylation in epigenetic gene regulation and brain function. Genes. 2017; (8): e148.

12. Liu XS, Wu H, Krzisch M, Wu X, Graef J, Muffat J, et al. Rescue of Fragile $X$ syndrome neurons by DNA methylation editing of the FMR1 gene. Cell. 2018; (172): 979-92.

13. Lau $\mathrm{C}-\mathrm{H}$, Suh $\mathrm{Y}$. In vivo epigenome editing and transcriptional modulation using CRISPR technology. Transgenic Res. 2018; 27 (6): 489-509.

14. Gomez JA, Beitnere U, Segal DJ. Live-animal epigenome editing: Convergence of novel techniques. Trends Genet. 2019; 35 (7): 527-41.

15. Sacca F, Puoro G, Antenora A, Marsili A, Denaro A, Piro R, et al. A combined nucleic acid and protein analysis in Friedreich ataxia: Implications for diagnosis, pathogenesis and clinical trial design. PLoS ONE. 2011; 6 (3): e17627.
16. Plasterer HL, Deutsch EC, Belmonte M, Egan E, Lynch DR, Rusche JR. Development of frataxin gene expression measures for the evaluation of experimental treatment in Friedreich's ataxia. PLoS ONE. 2013; 8 (5): e63958.

17. Hebinck J, Hardt C, Schols L, Vorgerd M, Briedigkeit L, Kahn CR, Ristow M. Heterozygous expansion of the GAA tract of the X25/ frataxin gene is associated with insulin resistance in humans. Diabetes. 2000; 49 (9): 1604-7.

18. McCormick A, Farmer J, Perlman S, Delatycki M, Wilmot G, Matthews K, et al. Impact of diabetes in the Friedreich ataxia clinical outcome measures study. Annals of Clinical and Translational Neurology. 2017; 4 (9): 622-31.

19. Абрамычева Н. Ю., Федотова Е. Ю., Нужный Е. П., Николаева Н. С., Клюшников С. А., Ершова М. В. и др. Эпигенетика болезни Фридрейха: метилирование области экспансии (GAA)n-повторов гена FXN. Вестник Российской академии медицинских наук. 2019; 74 (2): 80-7.

20. Essebier A, Wolf PV, Cao MD, Carroll BJ, Balasubramanian S, Boden M. Statistical enrichment of epigenetic states around triplet repeats that can undergo expansions. Front Neurosci. 2016; (10): 92.

21. Greene E, Mahishi L, Entezam L, Kumari D, Usdin K. Repeatinduced epigenetic changes in intron 1 of the frataxin gene and its consequences in Friedreich ataxia. Nucleic Acids Research. 2007; 35 (10): 3383-90.

22. Castaldo I, Pinelli M, Monticelli A, Acquaviva F, Giacchetti M, Filla $A$, et al. DNA methylation in intron 1 of the frataxin gene is related to GAA repeat length and age of onset in Friedreich ataxia patients. J Med Genet. 2008; 45 (12): 808-12.

23. Al-Mahdawi S, Pinto RM, Ismail O, Varshney D, Lymperi S, Sandi C et al. The Friedreich ataxia GAA repeat expansion mutation induces comparable epigenetic changes in human and transgenic mouse brain and heart tissues. Hum Mol Genet. 2008; (17): 735-46.

24. Patil V, Ward RL, Hesson LB. The evidence for functional non-CpG methylation in mammalian cells. Epigenetics. 2014; 9 (6): 823-28.

25. Fuso A, Lucarelli M. CpG and non-CpG methylation in the dietepigenetics-neurodegeneration connection. Curr Nutr Rep. 2019; 8 (2): 74-82.

26. Li K, Singh A, Crooks DR, Dai X, Cong Z, Pan L, et al. Expression of human frataxin is regulated by transcription factors SRF and TFAP2. PLoS ONE. 2010; 5 (8): e12286.

27. Al-Mahdawi S, Sandi C, Pinto RM, Pook MA. Friedreich ataxia patient tissues exhibit increased 5-hydroxymethylcytosine modification and decreased CTCF binding at the FXN locus. PLoS ONE. 2013; 8 (9): e74956. 